\title{
Blood on their hands: How heroines in biblical and Apocryphal literature differ from those in ancient literature regarding violence
}

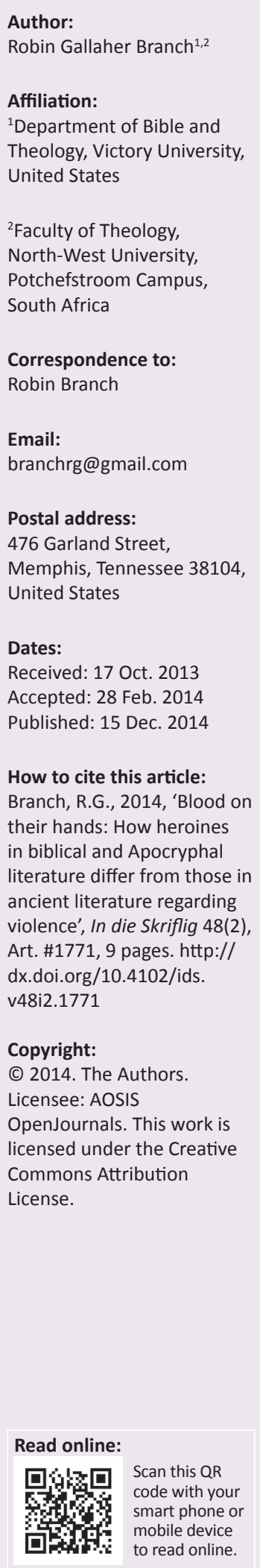

Deborah and Jael, Esther, and Judith are four biblical and Apocryphal heroines with blood on their hands. Their stories figure in the following passages: Judges 4-5, when Jael killed the Canaanite commander Sisera; Esther 8, when Esther pleaded with Xerxes to allow her people to defend themselves; and Judith 8-16, when Judith devised and fulfilled a plan to assassinate the Assyrian general, Holofernes. These texts exonerate them. A study of selected heroines in mythology and in classical works by Herodotus, Homer and Tacitus reveals interesting comparisons. This article includes character studies of stories about the Amazons, women warriors who mutilated their bodies to better aim a bow; Tomyris, who won a battle against Cyrus and put his head in a sack of human blood; Anchita, a Spartan mother who sanctioned sealing her son alive in the temple of Minerva; and Boadicea, who led a rebellion against Rome in which 80000 Britons perished. The article finds that, in contrast to the women of other cultures, Deborah and Jael, Esther, and Judith responded with violence to crises only when their people were threatened. Their successful actions are limited to the aggressors, within a time limit, and, arguably, tempered with mercy.

Met bloed aan die hande: Hoe heldinne uit die bybelse en Apokriewe literatuur verskil van dié uit die klassieke literatuur ten opsigte van geweldpleging. Debora en Jael, Ester, en Judit verteenwoordig vier heldinne uit die Bybelse en Apokriewe literatuur met bloed aan die hande. Hulle verhale word in Rigters 4-5 weergegee, waar Jael vir Sisera, 'n Kanaänitiese kommandant, vermoor het; in Ester 8, waar Ester by Xerxes 1 gepleit het om haar volk toe te laat om hulleself te verdedig; en in Judit 8-16, waar Judit 'n plan beraam én uitgevoer het om die Assiriese generaal, Holofernes te vermoor. Hulle word egter in hierdie teksgedeeltes onthef van skuld. 'n Studie van heldinne uit die mitologie en die klassieke werke van Herodotus, Homeros en Tacitus onthul interessante ooreenkomste. Hierdie artikel bespreek karakterstudies uit die verhaal van die Amasone - vrouekrygers wat nie geskroom het om hulle eie liggame te skend ter wille van die beter hantering van hulle wapens nie; die verhaal van Tomyris, wat 'n geveg teen Cyrus wen en sy kop in 'n sak, gevul met menslike bloed, geplaas het; Anchita, 'n Spartaanse moeder wat haar goedkeuring gee om haar seun lewend in tempel van Minerva af te seël; en Boadicea, wat 'n rebellie teen Rome aangevoer het waarin 80000 Britte omgekom het. Die slotsom van hierdie artikel is dat Debora en Jael, Ester, en Judit, in teenstelling met vroue uit ander kulture, hulle in krisistye tot geweldpleging gewend het slegs wanneer hulle volksgenote bedreig is. Hulle eenmalige dade is net tot die aggressors beperk en word waarskynlik deur 'n gevoel van erbarming getemper.

\section{Introduction}

This article starts with summaries of the biblical and Apocryphal accounts of the deeds of Deborah and Jael in Judges 4-5, and Esther and Judith in the books bearing their names. ${ }^{1}$ It then recounts selected stories from ancient literature that bear similarity to the three stories of the above-mentioned four women. ${ }^{2}$ It groups the three stories in sections and then comments on how they relate to the selected tales from antiquity. Employing a literary methodology, the article includes insights about character, plot, time, setting, tone, point of view and conflict. ${ }^{3}$ Throughout this article, the author appreciates the stories in both the biblical and ancient texts and notes that

\footnotetext{
1.This article recognises the Bible presents detailed character portraits of the named women with blood on their hands.

2.For the purposes of this article, the Book of Judith is grouped with biblical literature and is recognised as canon by the Catholic and Orthodox churches and as extra-biblical and Apocryphal literature by Jews and Protestants respectively (Hill \& Walton 2000:393)
}

3.See Lostracco and Wilkerson (2008) for literary elements in stories and Alter (1981) for his insights on Hebrew Bible narration. 
literature offers vignettes as well as insights into human life. These may well differ from and be a complement to the insights offered by natural science, philosophy and history. See Flory (1969:99-109) for an elaboration of this idea.

\section{Deborah and Jael}

The story of Deborah and Jael in Judges 4 and 5 is the substance of epic poems. The tale contains age-old elements of great drama: heroes and villains, courage and cowardice. Emotions that rage within the human soul as well as deceit, trickery, lust, greed, hate, fear, patriotism, and murder are there. ${ }^{4}$ Other elements likewise make their stories most interesting. As a military leader, the Spirit of Yahweh empowers Deborah (see Schwab 2011:41). Yahweh, the God of Israel, actively and terrifyingly takes part in this conflict between the oppressed Israelites and the chariot-riding Canaanites, a conflict known in scripture as Deborah's War. The primary means Yahweh uses in delivering his people from a 20-year long Canaanite oppression is the leadership of the prophetess Deborah. Also receiving textual acclaim is her general, Barak, from the tribe of Naphtali, and the Kenite woman Jael, who murders the fleeing Canaanite general Sisera (Jdg 4:1-7, 11, 17-21; 5:24-27, 31). Deborah - judge, prophetess, general, wife and songstress - stands amongst the Bible's most interesting figures, and Jael amongst one of its most controversial.

The setting started in Ephraim's hill country, switched to Mount Tabor and Jael's tent, and concluded on a battlefield with a song-filled victory celebration. ${ }^{5}$ The time, another important literary tool, ranges between 1281 and 1125 BC and before the monarchy, scholars estimate (Goslinga 1986:234; Bright 1981:179).

The text pauses on Jael and the events in her tent. First, it renders the historical and economic ties of Jael and her husband, Heber, to the Canaanites, and his family's link to Moses, for Heber is a descendant of Jethro, the father-in-law of Moses (Encyclopaedia Judaica 1971, 9:1247).

When Jael sees Sisera, she beckons him to come into her home, a tent. He must have looked battle weary, for the text says he had abandoned his chariot, fled by foot and was the sole survivor of the Canaanite army (Judges 4:15-16). Rabbinic tradition emphasises Jael's charms. She was not only beautiful, but also her voice aroused desire (Encyclopaedia Judaica 1971, 9:1247). She soothed Sisera with milk and covered him. He commanded her to stand guard before he fell asleep. She got a tent peg and with one blow, drove it through his temple. He died, of course (Jdg 4:18-21).

According to the traditional reading, hospitality prevailed in Jael's tent - and was broken. Beguiled by beauty,

\footnotetext{
4.See Lostracco and Wilkerson $(2008: 1-10,19-24)$ for a detailed explanation of plo and conflict.

5.Deborah's Song, perhaps the oldest poem in the Hebrew Bible, describes Yahweh's wrath and dominion over nature (Boman 1960:102) and God's ability to save his people.
}

duped by existing economic ties and refreshed by food, Sisera fell asleep - and never awakened. Murder replaced hospitality - at least seemingly. Was Jael a ruthless woman and her deed an outrageous act (see Elliott 1953:715; Myers 1953:717)? Was her deed morally unjustified and did she break accepted rules of hospitality (see Keil \& Delitzsch 1960:306, 323)? Should her deed be read as a counter reading against an 'exultant spirit of revenge' (see Cundall 1968:86)? Well, maybe.

However, rabbinic tradition counters that Sisera had seven sexual relations with her before he slept, exhausted, 'but she derived no gratification from these acts' (Encyclopaedia Judaica 1971 9:1247). Rape, if it occurred, certainly nuances this story (see Schwab 2011:77-97). Schwab (2011:83-87) is probably correct when he claims that a sexual encounter took place. Deborah sings that Sisera's death earns Jael the title 'most blessed among women' (Jdg 5:24).

\section{Esther}

In the Book of Esther, a beautiful Hebrew girl named Esther won the ancient equivalent of a beauty pageant. Chosen amongst a bevy of virgins throughout the realm of Xerxes, the world's most powerful man, Esther became his queen. Significantly for the book's entwining themes that form the story's plot, the text states that Xerxes loved Esther (Es 2:17; Branch 2009:681). It seems to be love at first sight, thereby setting the tone for a happy ending.

This historic event took place during the exile of the Jews; the setting is Susa, the capital of Persia, and primarily in the palace of Xerxes. The book's larger theme concerns a seemingly foolproof plot to annihilate the Jews throughout Xerxes' kingdom. On a smaller scale, the text dwells on the individual heroism of this young Jewish woman, unexpectedly forced to save her people. Esther clearly ranks in the tradition of political saviors in the biblical text who happen to be women including Deborah and Jael, Judith, the Hebrew slave girl in Exodus 2:1-10, and the wise woman of Abel Beth Maacah (2 Sam 20; see Branch 2010:63-81).

Esther began her marriage by keeping her Jewish identity secret, thus obeying instructions from her older relative, Mordecai. The secret adds literary suspense. Xerxes agreed to his counselor Haman's request: that all bow to him. Mordecai refused, presumably on ethical and religious grounds, because Haman was the descendant of Agag, the Jews' ancient enemy (3:1-36). Infuriated, Haman pursued not only Mordecai's death, but also the deaths of all Jews in Xerxes' kingdom (3:6). He presented a decree outlining his plans to Xerxes, and Xerxes signed, apparently with no investigation as to its merits and no thought to economic or moral consequences. Edicts were dispatched throughout the kingdom stating the time and date for the Jews' annihilation. The two men celebrated with a drink (3:15).

6.References in this section only reflecting the chapter and verses, refer to the book, Esther. 
Acting independently, Esther risked her life to come unbidden to the king. ${ }^{7}$ Demurely, she requested his and Haman's presence at an intimate banquet. The men came and enjoyed themselves; the king knew she wanted something from him. Using wisdom, allure and charm, she invited them to a second banquet (5:7). Again, hospitality seemingly prevailed. Yet the next day, once her husband and guest were wined and dined, Esther declared her life was in danger, revealed her identity, and pointed to the culprit, 'The evil Haman!' The king, incensed, ordered Haman's death (7:1-9)

\section{Round One to Esther (see Hamilton 2001:536)}

However, the peril continued for her and her people. ${ }^{8}$ The edict must be nullified. Esther followed through and negotiated (Branch 2009:687). Tension, a literary tool, mounted. Although re-using her successful tactics of coming before Xerxes as wife, and with confidence boldly risking her life for the pleasure of his company, Esther varied them a bit (8:1-6). Risking her life yet again, Esther again approached the king unbidden, fell before him, and pleaded for the lives of her people and herself. The king ordered that decrees be written enabling the Jews to defend themselves (Hamilton 2001:536-537).

\section{Esther also wins Round Two (8:7-17)}

The biblical text records the consequences of this action. Instead of defenselessly awaiting annihilation, the Jews make the necessary fortifications to protect themselves. They meet the onslaught with such courage and recognised character throughout the kingdom that neighbours fear them (9:1-2). The Jews' stature in public opinion rises throughout the kingdom (9:2). Mordecai becomes Xerxes' counselor (9:3-4).

The Jews kill 500 of their enemies in Susa in two separate instances (including the 10 sons of Haman) and 75000 throughout Xerxes' kingdom (9:12-16). ${ }^{9}$ Significantly, the Jews refrain from plundering their victims (9:10, 16; Hamilton 2001:537). The book ends triumphantly with Esther firmly in place as Xerxes' wife and trusted ally, and Mordecai as Xerxes' second in command and esteemed advisor (see Hamilton 2001:537). In a court filled with intrigue and murderous agendas, Xerxes, Esther and Mordecai worked as a team for the betterment and deliverance of the Jews and what the biblical text presents as the overall betterment of Xerxes' kingdom (Branch 2009:685).

7.The Additions to the Book of Esther add Esther's prayer to God that takes place before she goes unbidden to the king. In that prayer she says the following: 'Help me who am alone and have no helper except you, for I am risking my life' (Moore 1977:208).

8.See Grooves (2003:109) and Branch (2009:682) for more insights on Esther's peril.

9.Jewish tradition mentions that Xerxes dreamed of his vizier Haman bending over him with a sword and ready to kill him (Rappoport 1995:271). Xerxes maintained that Haman treacherously tried to take the life of Esther and have his dominion brought Haman treacherously tried to take the life of Esther and have his dominion brought
to destruction (Josephus 1985:242). Evidently Haman planned to overthrow Persia to destruction (Josephus 1985:242). Evidently Haman planned to ove
'in a coup for his own Macedonian people', Wolfe (2011:111) adds.

\section{Judith}

The Book of Judith tells the story of the ignominious defeat of the Assyrians, an army bent on world domination, by the hand of a Hebrew woman (Jdt 13:14). ${ }^{10}$ The book's amasing heroine, Judith, introduced as a devout, shapely, beautiful and wealthy widow $\left(8: 4,7^{11}\right)$, exhibits characteristics showing her as the equal of Israel's finest warriors. Indeed her beheading of Holofernes, the invading Assyrian general - in his own tent, with his own sword, and surrounded by his own, formerly victorious, army - marked her as a political redeemer in Israel - equivalent with David (see Branch 2012a; 2012b).

The book's plot is simple. Once again a localised despot became an international tormentor and sought world dominion. This time the despot was Nebuchadnezzar, ruler of Assyria. Feigning shame, because other world leaders ignored him, Nebuchadnezzar ordered his general, Holofernes, to gather troops, engage in war and conquer the world. ${ }^{12}$ Holofernes and his armed forces moved west, inflicting a swath of revenge by burning cities and plundering sheepfolds (2:26-27; Branch \& Jordaan 2009:402).

They encounter resistance from Bethulia, a backwater town located at the entrance of the narrow corridor leading to Jerusalem. ${ }^{13}$ Judith enters the book bearing her name when the Assyrians cut off Bethulia's water supply $(7: 7 ; 4: 7)$. The siege, which has lasted 34 days, has made the Bethulians fractious, thirsty and bitter (7:20, 29). Uzziah and the town's other magistrates succumb the citizens' demands and say they will surrender to the Assyrians in five days - unless the Lord takes pity (7:29-30). Upon hearing this, Judith summoned them to her home (8:10; see Branch 2012a; $2012 b)$. Her action sets the tone for the rest of the book, for it marks her as a self-confident leader - indeed a commanding presence. She said she had a secret plan to deliver the city. Believing her, the magistrates arranged for her and her maid to leave the city at night.

Judith dressed carefully, knowing the success of her ruse and assassination plan depended upon her appeal as a seductress (cf. Branch 2012a; 2012b). ${ }^{14}$ She had a bath and richly perfumed herself, fixed her hair, selected a festival dress and put on a tiara as her battle garb's finishing touch (10:3). She accessorised herself with rings, bracelets, anklets, earrings, other jewelry and attractive sandals (10:4). Dressed 'to catch the attention of the men who would see her' (10:4), Judith and her maid set forth at night down the valley, fully intending to be captured. Predictably stopped by an Assyrian

10.Much of the material in this section on Judith comes from Branch $2012 \mathrm{a} ; 2012 \mathrm{~b}$.

11. References in this section only reflecting the chapter and verses, refer to the book, Judith.

12.Brueggemann (2009:19) notes that a monopoly of power like that of Nebuchadnezzar and Holofernes must be defeated.

13.A number of historical facts show that the Book of Judith is a tale with moral teachings. For example, the historical Nebuchadnezzar ruled Babylon, not Assyria. Furthermore, there is no narrow corridor leading to Jerusalem and Bethulia is nonexistent (see Branch 2012a; 2012b).

14.The whole paragraph is based on these two sources 
border patrol and escorted by 100 men directly to Holofernes (10:17), she readily spun a tall tale with just enough facts to be believed. Throughout the book, it seems Judith merely smiles and men collapse $(10: 7,14,19,23)$. Wisely appealing to their senses of sight and smell, she captivates them. Her weapons of warfare are sensual and material.

Welcomed to the camp, she and her maid established a routine of bathing nightly at a spring outside the camp. Holofernes allowed them safe passage through the Assyrian lines. Within a few days, Holofernes, intented on seduction, sent his aide, Bagoas, to invite Judith to dine alone with him (Branch 2012c:77). In the intimate banquet set in Holofernes' tent, Judith simply reclined on lambskins, nibbled her food brought from Bethulia, and flattered the general by telling him 'today is the greatest day of my whole life' $(12: 15,18$, 19; see Branch 2012a; 2012b). She presented such a beguiling picture that the infatuated Holofernes, beset with lust, drank himself into senseless and fatal oblivion (12:16, 20; see Branch 2012a; 2012b).

Alone and undisturbed by tactful Assyrian servants, Judith beheaded Holofernes with two strokes from his own famous sword - praying beforehand, of course (13:4-7; see Branch 2012a; 2012b). She rolled his corpse to the floor (an action that dishonoured the body), pulled down a jeweled canopy from above his bed, walked out of the tent, and handed his head to her waiting maid who put it in the food sack (13:9-10). Together the women walked through the Assyrian lines as they did on other nights, allegedly to pray and bathe. This time skipping the prayer-and-bath routine, they headed straight up the mountain to Bethulia's gates.

Displaying his head, she told her story whilst proclaiming her chastity. Believing her, Uzziah declared that Judith was blessed 'by the Most High God above all other women on earth' (13:18). This verse, an echo of Deborah's vindication of the murder of Sisera that Jael committed (Jdg 4:21, 5:24-26), is pivotal in Roman Catholic theology, for it is also said of Mary (Lk 1:42, 48; see Branch 2012a; 2012b).

\section{Other heroines in ancient literture}

The stories of other women in ancient literature will now be discussed and compared with the above-mentioned stories. The stories, selected during my reading of classical literature, reflect the limitations of randomness and this article's space constraints. Furthermore, the Bible and ancient literature contain more stories of men than women, thereby limiting my selection. My research is not exhaustive, but instead raises the possibility of further study, comparison, and analysis. What follows are my preliminary findings.

\section{Mythology}

\section{Demeter}

Edith Hamilton (1969:49-54) tells the story of the grief of Demeter, goddess of harvest wealth, over the fate of her daughter Persephone, the maiden of spring. The story highlights the vengeance the Greeks saw their gods mete on Earth, for Demeter in her sorrow 'withheld her gifts from the earth, which turned into a frozen desert' (Hamilton 1969:49).

Lust initially prevails. Hades, the lord of the underworld, 'king of the multitudinous dead', kidnapped Persephone when she strayed too far from the protective care of her companions (Hamilton 1969:50). The kidnapping turned out to be the connivance of Hades and his brother, Zeus, the father of Persephone.

Beset with grief, Demeter searched for 'slim-ankled' Persephone (Foley 1994:2). None on earth knew her whereabouts, but Demeter discovered from the Sun that Persephone was 'among the shadowy dead' (Hamilton 1969:50). Demeter retaliated with anger, ordaining that the earth, likewise, be wasted away as she wasted away with grief for Persephone. She decreed worldwide famine.

Hamilton (1969:52) writes: 'That year was the most dreadful and cruel for mankind over all the earth. Nothing grew ... It seemed the whole race of men would die.'

Comment: Yes, the famine lifted, and Persephone returned to earth's surface for eight months each year. However, Demeter's action shows a goddess purposefully inflicting suffering on powerless mortals in what seems to be a choice to make others suffer whilst she suffers. In contrast, God promises to keep the covenant people alive during a time of famine (Ps 37:19). Furthermore, Deborah and Jael, Esther, and Judith work for the common good of the covenant people when they face oppression and attack.

\section{Medea}

Medea, the Sun's granddaughter, likewise is a colorful, cruel and powerful semi-divine figure. Medea and Jason, the hero of many battles and adventures, married. Their story resonates with modern-day issues like commitment and revenge.

They quickly had two children. Jason promised faithfulness, but his eyes wandered to Glauce, daughter of Creon, King of Corinth. ${ }^{15}$ Creon banished Medea and her children from Corinth because he feared rivalry between the women and rightly so, it turns out.

Medea left Corinth but sent wedding gifts to Glauce: a dress and crown of pure gold, both smeared with magic ointment. Glauce should have suspected the gifts and motives of the sender, for Medea was known for her ability to mix potions and to plan revenge. Vanity and materialism prevailed, however, and when Glauce donned them, a flame wrapped around her like a sheet. She met a terrible death, for the robe stuck to her skin and when she tried to shake the crown off her head, the fire burnt twice as fiercely (Torrance 2007:289). Her father, Creon, likewise died whilst trying to save her 15.See Torrance 2007:289 and Stavropoulou 1997:104-105 for a more detailed story. 
(Stavropoulou 1997:104-105). Torrance (2007:289) correctly writes that the 'fire is a powerful image both of passion and revenge'. Continuing her rampage, Medea killed her children.

Comment: In a somewhat similar way, the biblical figure Athaliah also killed her family members. The slaughter secured her the throne (2 Ki 11:1-21; 2 Chr 22:1-23:21). Her story is beyond the scope of this article (see Branch 2004:537560 for the detailed version). The biblical text forbids these actions: murder and adultery (Ex 20:13-14). Furthermore, 'fathers shall not be put to death for their children, nor children put to death for their fathers; each is to die for his own sin' (Dt 24:16, NIV).

\section{Norse gods}

War's glorification presents a major theme in ancient literature in the Mediterranean world and elsewhere, including Norse culture. In Norse mythology, Odin is a predominant god, characterised as the spirit of the universe and the wisdom that comes with age. Norse mythology contains the tradition of warrior maidens (Roberts, Roberts \& Katz 1997:141). Called Valkyrs, these spirit maidens function as virgin demigoddesses, roaming the battlefields looking for warriors dying with 'battle-lust in their eyes and blood on their hands' (Roberts et al. 1997:144). These chosen fallen are carried to Valhalla, a magnificent palace where their new existence consists of rounds of hearty eating and drinking, fighting to the death, and miraculous healing. This routine continues daily, eternally, under Odin's watchful pleasure (Roberts et al. 1997:144).

Comment: Greek, Roman and Norse mythologies glorify war. In contrast, the biblical text presents war as probable but infrequent and entered upon reluctantly. Indeed, there is an absence in Scripture of glorying in military prowess (McDonald 2004:282-283). ${ }^{16}$ However, the covenant people were encouraged to be prepared for war to defend themselves and others within the covenant. Deborah chastises the tribes of Reuben, Gilead, Dan and Asher for not joining the battle - a holy war (Jdg 5:15-17). These cowards stayed at the campfires, whistled to their flocks, and remained safe. Wenham (2010:224-225) rightly notes that the laws on war (Dt 20:10-19) remarkably list caveats for exemption from being called up for war like being a new groom or being a new homeowner or even being scared. Furthermore, David allowed for exhaustion as a reason not to go to battle. These same tired soldiers could guard the supplies and still received plunder from any battle (2 Sam 30:21-25). Hence, the covenant people enter war with their heels dug in.

16.The story of the conquest of the land is outside the scope of this article. However, McDonald's insights on violence contain merit. She (McDonald 2004:283) rightly notes that at times, Israel cannot live at peace amongst its neighbours. The thrust notes that at times, Israel cannot live at peace amongst its neighbours. The thrust to violence (McDonald 2004:284). McDonald (2004:282-283) sees experiences like the Exodus from Egypt and the conquest of Canaan as pointing toward God 'as the source of bounty'. Furthermore, those who glory in possessions and rejoice over their enemies close themselves off from others and from God (McDonald
2004:

\section{Artemis and Hera}

In the Iliad, Artemis is known as the queen of wild things and the hellcat sister of Apollo (Homer 1997, 21:483-485). During the Trojan War, the gods took sides. Hera, queen of the gods of Olympus, wife of Zeus, was pro-Greek. Artemis, daughter of Zeus and Leto, was defiantly pro-Trojan. Hera and Artemis fought in the heavens whilst the Trojan War played out on earth.

Hera confronted Artemis in bold language. ${ }^{17}$ Hera's furious putdown of her stepdaughter and political rival contained venom (Homer 1997, 21): ${ }^{18}$

Do you think you can cross me like this, You bitch? I'm not an easy opponent ...You'd do better to hunt wild game, deer In the woods, than tangle with your betters. (pp. 493-502)

Comment: The biblical text recounts a different kind of interaction in heavenly council meetings. ${ }^{19}$ The Book of Job indicates regular council sessions in which even the adversary, Satan, attends (Job 1:9-12; 2:1-7). In 1 Kings 22:19 and Isaiah 6 , the prophets Micaiah and Isaiah participate in heavenly councils meetings. Jeremiah 22:16 indicates that false prophets do not attend the Lord's council meetings in which they would hear the word of the Lord. Significantly, true prophets of the Lord hear his word and deliver it accurately, as Deborah did, according to biblical text. In addition heavenly elements, the stars, obey divine directives and fight against Sisera (Jdg 5:20).

\section{Amazons}

The Amazons were fierce women warriors known for their hatred of men (Hamilton 1942:287) and skilled in using bows and arrows, spears, darts and double battle-axes (Guliaev 2003:113). The Amazons ruled a number of cities and favoured only female babies. Their sons were sent away, killed or perhaps mutilated by their mothers (see Bulfinch 1970:145). The Amazons themselves cut off their own right breasts 'in order to be able to use the bow more easily' (Kirkwood 1959:7).

Comment: Biblical text speaks against self-mutilation and tattoos (Lv 19:28). It says children are a reward from the Lord (Ps 127:3). It traces genealogy through the male line (1 Chr $1: 1-28 ; 2: 1-17)$, but gives a father and mother equal responsibility for raising their children $(\operatorname{Pr} 1: 8)$. In these and other ways the Bible states views in conflict with the Amazons' traits. Although Deborah acted as a general, there is no indication she engaged in physical combat.

17.The Illiad's language illustrates why, after 2700 years, the book and its companion the Odyssey, remain best sellers (Myrsiades 2008:xi).

18.In comparing Homer and Herodotus as writers, Flory (1969:109) maintains that Homer, who knew how to write, lived in a time devoid of the 'cultural trappings' that dictated how to write. By the time of Herodotus, writing was 'a cultural fact' (Flory (1969:109) with recognised patterns like repetition and digression.

19.Miller (2006:23ff.) links the idea of a divine council in Scripture with that of councils in literature of the ancient Near East and cites the role of the divine council of cosmic warriors in Ugaritic texts. 


\section{Herodotus' examples of women who wage war and enact personal vengeance \\ Candaules, Gyges and the wife of Candaules}

Herodotus tells a story of male boasting and voyeurism that ends fatally for the husband who arranged for his aide to view his wife naked..$^{20}$ The story also highlights a woman's revenge. ${ }^{21}$

Candaules, son of Myrsus and king of Sardis, tells his aide, Gyges, son of Dascylus, about the beauty of his wife. He wanted Gyges to see her naked as she prepared to come to the bed. Gyres protested, calling Candaules' speech 'unwise' (Herodotus 1942, 1:8). Candaules prevailed and Gyres hid in the chamber awaiting the nightly ritual. However, the unnamed wife saw him leaving the apartment.

Summoning Gyges in the morning, she gave him these choices: to slay Candaules and become her lord and take over the Lydian throne 'or die this moment in his room. So you will not again, obeying all behests of your master, behold what is not lawful for you' (Herodotus 1942, 1:11).

Gyges chose his own life and asked the woman how to proceed. She replied that Candaules should be killed whilst sleeping in the place 'where I was by him and shown naked to you, and let the assault be made when he is asleep'. The woman placed a dagger in Gyges' hand and hid him carefully behind the door as in the night before (Herodotus 1942, 1:11). Herodotus $(1942,1)$ continues:

Then Gyges, when the king had fallen asleep, entered privily into the chamber and struck him dead. Thus did the wife and kingdom of Candaules pass into the possession of his follower Gyges. (p. 12)

Comment: The unnamed wife of Candaules experienced shame because of her husband's plan. She took revenge upon him and arranged for his murder. Granted, Candaules' deed wronged her and broke a sacred trust between them as husband and wife. The biblical text speaks again of a different standard. Vengeance belongs to the Lord; to avenge remains his prerogative (see Dt 32:35). However, the biblical text allows humanity to voice opinions. The psalmist in Psalm 139:19 calls upon God in strong language to slay the wicked. The psalmist stresses his hatred for those who rise against God (Ps 139:21-22). After stating his views, the psalmist leaves the matter with the Lord. Deborah and Jael, Esther, and Judith refrain from taking revenge.

20.Flory (1969:104) writes that Herodotus' works contain many sexual scenes and many examples of 'female jealousy, revenge, murder, and mutilation'. He (Flory 1969:105-106) goes on to elaborate on what he sees as Herodotus excessive personal interest in sexual relations, those excluded from enjoying sexual relations, and details about sexual anatomy by highlighting many of the erotic stories in his

21.The story is typical of Herodotus' style which focuses on revenge, requital, and extraordinary and unexpected happenings (Strid 2006:394).

\section{Cyrus and Tomyris}

Herodotus tells the story of the death of Cyrus, one of the world's great conquerors, and the shame inflicted on his body. Arguably, his death could have been in a different way if he had followed the advice of Tomyris, a wise but vengeful queen.

Cyrus' forces engaged those of Spargapises, son of queen Tomyris. After the battle, Spargapises hosted a banquet in which he and his men got drunk and slept. His youth and inexperience prove no match for wily Cyrus. Herodotus (1942, 1:211) writes that 'Cyrus arrived, slaughtered a great multitude, and made even a larger number of prisoners. Amongst these last was Spargapises himself.' Hearing of this, Tomyris sent a herald to Cyrus saying (Herodotus 1942, 1):

Bloodthirsty Cyrus, pride not yourself on this poor success ... Restore my son to me and leave the land unharmed, triumphant over a third part of the host of the Massagetae. Refuse, and I swear by the sun, the sovereign lord of the Massagetae, bloodthirsty as you are, I will give you your fill of blood. (p. 212)

Spargapises, upon awakening, committed suicide. Meanwhile, Cyrus disregarded Tomyris' words, wise and prophetic though they are. A battle commenced. Cyrus falls, after ruling the world for 29 years. Herodotus $(1942,1)$ chronicles Tomyris' actions:

Search was made among the slain by order of the queen for the body of Cyrus, and when it was found the queen took a skin, and, filling it full of human blood, she dipped the head of Cyrus in the gore, saying, as she thus insulted the corpse, 'I live and have conquered you in fight, and yet by you I am ruined, for you took my son with guile; by this I make good my threat, and give you your fill of blood. (p. 214)

Comment: Judith displayed the head of Holofernes from a sack, and Tomyris put the head of Cyrus in a sack filled with blood. The heads of fallen generals represent trophies in ancient literature and the biblical text. Jael beheaded Sisera and Haman and his sons were hanged. The stories studied in this article bear strong similarities in the matter of the head. Holofernes died by the hand of a woman and Cyrus proceeded to battle after a woman's warning. In the culture of the time, shame adorns the name of each man (see DeSilva 2002:101).

\section{Darius and Atossa}

Darius married many Persians including a girl named Atossa. At the proper time, Atossa engaged in an intimate conversation with Darius. She coos (Herodotus 1942, 3):

It seems to me strange, my lord, that, with the mighty power which is yours, you sit idle, and neither make any conquest, nor advance the power of the Persians. I think that one who is so young, and so richly endowed with wealth, should perform some noble achievement to prove to the Persians that it is a man who governs them. (p. 134)

Flattered, Darius replied (Herodotus 1942, 3):

Dear lady, you have uttered the very thoughts that occupy my brain. I am minded to construct a bridge which shall join our continent with the other, and so carry war into Scythia. In a brief space and all will be accomplished as you desire. (p. 134) 
And so Darius strived to conquer the world, and thousands died.

Comment: The stories of Atossa and Esther share the following: Both women studied their husbands and approached them in non-threatening even flattering ways. Both chose their words carefully and used their assets - their bodies, beauty and wifely status - advantageously. In other words, they advanced their causes. Arguably, Judith and Jael similarly relied on their ability to dazzle men.

\section{Pausanias and Anchita}

The following section refers to Guerber (1896:55): Pausanias, king of Sparta, unsuccessfully tried to rule Greece. According to the story, Pausanias proudly flaunted the victory he achieved over the Persians at Plataea. Pride compelled him to the desire to become king over all Greece. The Greeks, however, would have none of it.

Yet Pausanias persisted, copying Persian mannerisms, something that further annoyed his countrymen. He secretly offered to help the Persians in return for their making him king over Greece.

Upon learning of this, the Greeks seek to capture Pausanias. He took sanctuary in a temple of Minerva. Of course he could not be taken from the temple, so his countrymen sealed him inside it. ${ }^{22}$ His mother Anchita placed the first stone, saying that she preferred him to die rather than to remain alive as a traitor.

Therefore, left to starve, Pausanias indeed starved. However, as he breathed his last, the Greeks removed him from the temple and took him outside to die, ${ }^{23}$ for it was feared that his dying breath would pollute the temple and 'offend the gods'.

Comment: Deborah called herself a mother in Israel (Jdg 5:7). In the context of that remark, Deborah talked about leading Israel and purposefully doing good by shaking off the Canaanite yoke of oppression. Deborah also condemned the tribes who failed to come to the holy war, but stopped short of calling them traitors or commanding fellow Israelites to kill them. Instead, she held them to ridicule and taunted their cowardice with mentioning that they sat amongst the sheepfolds and piped songs to the flocks (Jdg 5:16). In these ways, her actions differ from those of Anchita and the Greeks.

\section{Amestris, wife of Xerxes}

Herodotus ends The Persian Wars with a sordid, horrific tale of lust, power, mutilation and murder (see Branch 2009:675676). Xerxes fell in love with the wife of his brother, Masistes.

\footnotetext{
22. Religious convictions, as in the case of the Greeks with Pausanias, are associated with live burials in the ancient world (Varhelyi 2007:278).

23.Perhaps another reason why the people removed Pausanias from the temple was that tombs become landmarks in the ancient world, and indeed are treated as such in the Homeric poems, Iliad and Odyssey (Grethlein 2008:28). Archaeology rightly notes that material objects - in this case a temple - have biographies and rightly notes that material objects - in this case a temple - have biographies and
preserve stories (Grethlein 2008:35). Quite likely on a subliminal basis the Greeks preserve storised this.
}

She refrained from reciprocating his advances. So Xerxes arranged the marriage of his son to Artaynta, a daughter of Masistes. Xerxes pursued her himself, and Artaynta reciprocated (Branch 2009:676).

All this angered Amestris, the wife of Xerxes. She plotted revenge and nagged Xerxes for a present during a banquet: the wife of Masistes. Xerxes, though horrified, had to yield, for Persian law required that none can be refused a request at a royal banquet (Strid 2006:398). Amestris ordered that the woman's breasts, nose, ears and lips be cut off and thrown to the dogs (Branch 2009:676). Amestris then sent her home where Masistes found her. He gathered his sons and attempted to overthrow Xerxes by trying to stir up a revolt against him at Bactria, but Xerxes responded with an armed force, slaying both Masistes and his army (Strid 2006:398; Herodotus 1942, 9:108-113).

Comment: Esther married a prototype of an oriental despot. Intrigue at Xerxes' court - amply supported by the biblical text and Herodotus - put lives in jeopardy. Esther entered the international stage with much reason to fear for her life. Yet the biblical record displays she walked gracefully into the halls of power and controlled herself with queenly confidence (Branch 2009:676). Wolfe (2011:118) notes that while Esther risked her life, and 'averted the eradication of her people', readers are nonetheless troubled at 'so much blood on the hands of one of the Bible's great heroines'. Whilst she (Wolfe 2011:119) dismisses the text as 'over-theto-self-defense fantasy', I see it as a justifiable response to annihilation. In contrast, Amestris' action is pre-meditated revenge and destruction upon the wife of Masistes.

\section{Tacitus chronicles Rome's glory Boudicea}

Tacitus, the pro-Roman historian, recounts many battles and political stories. One of these tells the story of a revolt in Rome's outer reaches, the Isle of Briton.

Prasutagus, king of Iceni, a tribe in Briton, did what he thought was a wise move when Roman legions invaded and conquered much of the island: he submitted to the Romans. He reasoned that his submission would enable his house and country to escape decimation. He was wrong, however! Roman centurions plundered both his kingdom and home. His wife, Boadicea, was outraged and the chastity of his daughters violated (Tacitus 1952, 14:31). Suetonius, leading Rome's 14th legion, carried on in his conquering mode, slaughtering an estimated 70000 (Tacitus 1952, 14:33).

Boudicea led a revolt against the Romans, successfully rallying her countrymen and garnering initial success. ${ }^{24}$

\footnotetext{
24.In all his writings, Tacitus favours Rome, but also writes believably of human nature. His stories of war, heroism and disaster display aspects of human nature (Miller 1977:14). By including the story of Boudicea and the reasons for her revolt, Tacitus continues his practice of inviting his readers to reflect on human life, human Tacitus continues his practice of inviting his readers to reflect on human life, human
behaviour and human war (Miller 1977:21).
} 
Encouraging her army, Boudicea boldly stated (Tacitus 1952, 14):

I am avenging lost freedom, my scourged body, the outraged chastity of my daughters. Roman lust has gone so far that not our very persons nor even age or virginity, are left unpolluted. But heaven is on the side of a righteous vengeance. (p. 35 $)^{25}$

Whilst all downtrodden people hope that 'heaven is on the side of a righteous vengeance', it was not true in this case. The story unfolds with typical Roman pugilism. ${ }^{26}$ Suetonius, the Roman general, likewise encouraged his army to fight the Briton barbarians, joking before battle that they will see 'more women than warriors' (Tacitus 1952, 14:36). Armed with more artillery, training, strategy and tactics, the Roman army easily routed the Britons, killing probably 80000 and taking only 400 casualties. Boudicea ended her life by means of poisoning herself (Tacitus 1952, 14:37). ${ }^{27}$

Comment: None of the biblical heroines took their own lives.

\section{Conclusion}

The stories of Deborah and Jael, Esther, and Judith give a biblical response to an insult prevalent in the Mediterranean world. Clearly it is not true, as the Persians say, that there is nothing worse than being called 'worse than a woman' (see Strid 2006:397). In these selected stories, four women won national acclaim for their courage, and saved their nation. The honor for the victory in the holy war, Deborah's War, goes to Jael. ${ }^{28}$ National gratitude, even in exile, comes to Esther. Spiritual accolades from a jubilant populace flow to Judith for the remainder of her long life.

Whilst this article presents initial research and prolonged study is needed, it nonetheless offers a demarcation between divergent concepts prevalent in the ancient world: firstly for the covenant people of Israel who followed an unseen God, and secondly for their neighbours who followed multiple gods. Self-interest dominates the stories in ancient literature. However, amongst the principles guiding the covenant people are the Ten Commandments (Ex 20), the holiness of God (Lev 19:1-2), and the character of God (Ex 34:6-7). Significantly concerning the latter, God's anger and punishment end. Similarly, the four biblical women refrained from pursuing their enemies in prolonged and unrestrained ways. In other words, mercy prevails (as it does with God). In each case, the women stood up to an enemy facing the covenant people and triumphed.

25.Tacitus uses a direct quotation here, a powerful literary technique. He lets Boudicea's words justify and support her actions. Boudicea speaks for herself, boldly giving her reasons for opposing Roman rule. Her powerful words unite public feeling to revolt against Rome. See Haynes (2004:33-61) for a thorough analysis of how Tacitus deftly structures his writings to both present a glorious, imperial Rome and to instruct his readers about harsh reality in the Roman empire, be it Germany or Britain.

26.Tacitus' writing style as a historian combines characterisation, emotion and a background sketch (Miller 1977:14).

27.Modern scholarship argues that Tacitus, in his writings, deftly positions himself by his choice of incidents and his creative interpretation of them to be the best interpreter of Roman rule and Roman leaders (see Cowan 2009:208).

28.Crook (2009:591) points out that honour and shame 'remain pivotal cultural values in the Mediterranean world'. This applies to both biblical text and other records.
In the biblical worldview, war overwhelmingly represents a last resort. Wenham (2010:224) points out that the 'desire for peace and the aversion to violence' underlie 'all biblical descriptions of war and homicide'. War, sin, violence and homicide indeed cross the biblical pages, but violence is presented straightforwardly as a consequence of sin, not something lauded for its own sake or taught as a lifestyle. ${ }^{29}$ Even during the Conquest, the Angel of the Lord would not say he sided with Israel (Jos 5.14; Schwab 2011:71). ${ }^{30}$

In Israel, war responds to oppression (as in the case of Deborah's War). Self-defense responds to a threat of annihilation (as when Esther seek legal measures that allow the Jews to defend themselves). Killing a brutal enemy army leader aborts the sacking of Bethulia (as in the case of Judith). Brueggemann (2009:65) points out that Yahweh sides with the oppressed against the powerful. In these three instances, oppressed Israel received help in unexpected ways from Yahweh. Unlikely women became both warriors and national heroes.

Significantly, Deborah and Jael, Esther, and Judith neither seek war nor employ pre-emptive strikes. With reluctance, they set a course that will either get them killed or leave them with blood on their hands. The concepts of ruling the known world and looking for more people to conquer, subdue, displace and enslave are on the whole foreign to the covenant people over biblical history. ${ }^{31}$ The prophetic texts speak of peace instead; indeed a time when 'the wolf will live with the lamb, the leopard will lie down with the goat, the calf and the lion and the yearling together; and a little child will lead them' (Is 11:6). The heroines in the three stories shared a similar mindset. They focused their actions on the perpetrators of oppression and war, limited their actions to these aggressors and their allies, set their actions within a specific time limit, and (arguably because of these reasons) tempered their actions with mercy. In other words, these women and Israel in general did not seek war for war's sake.

Yet another major difference between the Bible and ancient texts is the following: the heroes and heroines of the Hebrew Bible are great because 'God has acted in them or spoken to them' (see Boman 1960:113). Greatness, in the biblical sense, is not because of individual heroism or piety, although those characteristics certainly are there. The Bible proclaims that God's sovereign choice alone makes people great. Arguably, God puts people in strategic locations before a crisis occurs, trains them to succeed, and when the crisis comes, they succeed. Success and lasting acclaim clearly occur in the lives of these four remarkable women.

\section{See Wenham (2010:222-226) for a more lengthy argument}

30.Theology is progressive throughout the Bible. For example, we do not know all about God in Genesis 1:1. Schwab (2011:71) affirms this concept by adding that after the destruction of Jerusalem, God spoke to Ezekiel and stated that from now an an individual would stand before God based on his own behaviour (Ezk 18:1820). Previously, sin's consequences would extend for several generations (Ex 34:7; 20). Previou.

31.Perhaps an exception to this is the time of the Conquest. 


\section{Acknowledgements}

\section{Competing interests}

The author declares that she has no financial or personal relationship(s) which may have inappropriately influenced her in writing this article.

\section{References}

Alter, R., 1981, The Art of Biblical Narrative, Basic Books, New York.

Boman, T., 1960, Hebrew Thought compared with Greek, W.W. Norton \& Company, New York.

Branch, R.G., 2004, 'Athaliah, a treacherous queen: A careful analysis of her story in 2 Kings 11 and 2 Chronicals 22:10-23:21', In die Skriflig 38 (4), 537-560.

Branch, R.G., 2009, 'Teaching an Old Dog New Tricks: Herodotus Confirms Xerxes' Anger in The Persian Wars, and the Book of Esther Provides Insights on Ange Management', In die Skriflig 43(3), 669-693. http://dx.doi.org/10.4102/ids. v43i3.242

Branch, R.G., 2010, Jeroboam's Wife: The Enduring Contributions of the Old Testament's Least-Known Women, Baker Academic, Grand Rapids.

Branch, R.G., 2012a, Judith: A Remarkable Heroine, part 1, viewed 03 October 2013 from http://www.biblicalarchaeology.org/daily/people-cultures-in-the-bible/ people-in-the-bible/judith-a-remarkable-heroine/

Branch, R.G., 2012b, Judith: A Remarkable Heroine, part 2, viewed 3 October 2013,

Branch, R.G., 2012c, 'Joakim, Uzziah, and Bagoas: A Literary Analysis of Selected Secondary Characters in the Book of Judith', Old Testament Essays 25(1), 57-83.

Branch, R.G. \& Jordaan, P., 2009, 'The Significance of Secondary Characters in Susanna, Judith, and the Additions to Esther in the Septuagint', Acta Patristica et Byzantina 20(2), 389-416.

Bright, J., 1981, A History of Israel, 3rd ed., Westminster, Philadelphia.

Brueggemann, W., 2009, Divine Presence Amid Violence: Contextualizing the Book of Joshua, Paternoster/Thinking Faith, Colorado Springs.

Bulfinch, T., 1970, Bulfinch's Mythology: The Age of Fable the Age of Chivalry Legends of Charlemagne, Crowell Company, New York.

Cowan, E., 2009, 'Tacitus, Tiberius and Augustus', Classical Antiquity 28(2), 179-210. http://dx.doi.org/10.1525/CA.2009.28.2.179

Crook, Z., 2009, 'Honor, Shame, and Social Status Revisited', Journal of Biblical Literature 128(3), 591-611.

Cundall, A.E., 1968, Judges: An Introduction and Commentary, InterVarsity Press, Downers Grove.

DeSilva, D.A., 2002, Introducing the Apocrypha: Message, context, and significance, Baker Academic, Grand Rapids.

Elliott, P.P., 1953, 'Judges', in G.A. Buttrick (ed.), Interpreter's Bible, vol. 2. pp. 688-826, Abingdon, New York.

Encyclopaedia Judaica, 1971, 'Jael', in Encyclopaedia Judaica, vol. 9, Keter Publishing, Jerusalem, pp. 1247-1248.

Flory, S., 1969, 'The Personality of Herodotus', Arian 8(1), 99-109.

Foley, H.P. (ed.), 1994., The Homeric Hymn to Demeter: Translation, Commentary, and Interpretive Essays, Princeton University Press, Princeton.

Goslinga, C.J., 1986, Joshua, Judges Ruth, transl. R. Togtman, Regency Reference Library, Grand Rapids.

Grethlein, J., 2008, 'Memory and Material Objects in the Iliad and the Odyssey', The Journal of Hellenic Studies 128(1), 27-51.

Grooves, E., 2003, 'Double take: Another look at the second gathering of virgins in Esther 2:19a', in S.W. Crawford \& L.J. Greenspoon (eds.), pp. 91-110, The Book of Esther in Modern Research, Clark, London.
Guerber, H.A., 1896, The Story of the Greeks, American Book Company, New York, viewed on 03 October 2013, from http://www.gutenberg.org/files/23495/23495h/23495-h.htm

Guliaev, V.I., 2003, 'Amazons in the Scythia: New Finds in the Middle Don, Southern Russia', World Archaeology 35(1), 112-125. http://dx.doi. org/10.1080/0043824032000078117

Hamilton, E., 1942, Mythology, New American Library, New York.

Hamilton, E. 1969, Mythology: Timeless Tales of Gods and Heroes, Penguin Books, A Meridian Book, New York.

Hamilton, V.P., 2001, Handbook on the Historical Books: Joshua, Judges, Ruth, Samuel, Kings, Chronicles, Ezra-Nehemiah, Esther, Baker Academic, Grand Rapids.

Haynes, H., 2004, 'Tacitus's Dangerous Word', Classical Antiquity 23(1), 33-61. http:// dx.doi.org/10.1525/ca.2004.23.1.33

Herodotus, 1942, The Persian Wars, transl. G. Rawlinson, The Modern Library, New York.

Hill, A.E. \& Walton, J.H., 2000, A Survey of the Old Testament, Zondervan, Grand Rapids.

Homer, 1997, Iliad, transl. S. Lombardo, Hackett Publishing Company, Indianapolis.

Josephus, F., 1985, The Works of Josephus, Hendrickson, Peabody.

Keil, C.F. \& Delitzsch, F., 1960, Joshua, Judges and Ruth, William B. Eerdmans, Grand Rapids.

Kirkwood, G.M., 1959, A Short Guide to Classical Mythology, Holt, Rinehart \& Winston, New York.

Lostracco, J. \& Wilkerson, G., 2008, Analyzing Short Stories, Kendall/Hunt Publishing Company, Dubuque.

McDonald, P.M., 2004, God \& Violence: Biblical Resources for Living in a Small World, Herald Press, Scottdale.

Miller, N.P., 1977, 'Tacitus' Narrative Technique', Greece \& Rome 24(1), 13-22. http:// dx.doi.org/10.1017/\$0017383500019574

Miller, P.D., Jr., 2006, The Divine Warrior in Early Israel, Society of Biblical Literature, Atlanta.

Moore, C.A., 1977, Daniel, Esther, and Jeremiah: The Additions: A New Translation with Introduction and Commentary by Carey A. Moore, Doubleday, New York.

Myers, J.M., 1953, “'Judges.” Interpreter's Bible', vol. 2, in G.A. Buttrick (ed.), pp. 677826 , Abingdon, New York.

Myrsiades, K., 2008, 'Introduction: Homer: Analysis and Influence', College Literature 35(4), xi-xix.

Rappoport, A.S., 1995, Ancient Israel, vol. 3, Senate, London.

Roberts, T.R., Roberts, M.J. \& Katz, B.P. (eds.), 1997, Mythology: Tales of Ancient Civilizations, Metro Books, New York.

Schwab, G.M., 2011, Right in their Own Eyes: The Gospel According to Judges, P\&R Publishing, Phillipsburg.

Stavropoulou, M., 1997, Greek Mythology: Gods \& Heroes-he Trojan War-the Odyssey, transl Cox \& Solman, Ekdotike Athenon, Athens.

Strid, O., 2006, 'Voiceless Victims, Memorable Deaths in Herodotus', The Classical Quarterly 56(2), 393-403. http://dx.doi.org/10.1017/\$0009838806000401

Tacitus, P.C., 1952, The Annals and the Histories, Encyclopaedia Britannica, Chicago.

Torrance, I., 2007, 'The Princess's Gruesome Death and Medea 1079', The Classical Quarterly 57(1), 286-289. http://dx.doi.org/10.1017/S0009838807000262

Varhelyi, Z., 2007, 'The Specters of Roman Imperialism: The Live Burials of Gauls and Greeks at Rome', Classical Antiquity 26(2), 277-304. http://dx.doi.org/10.1525/ ca.2007.26.2.277

Wenham, G.J., 2010, 'Preaching from Different Texts', in G.J.R. Kent, P.J. Kissling \& L.A. Turner (eds), Reclaiming the Old Testament for Christian Preaching, pp. 215-232, IVP Academic, Grand Rapids.

Wolfe, L.M., 2011, Ruth, Esther, Song of Songs, and Judith, Cascade Books, Eugene. 